\title{
The social network of children with special healthcare needs in the (in)visibility of nursing care
}

\author{
Juliana Rezende Montenegro Medeiros de Moraes ${ }^{1}$ \\ Ivone Evangelista Cabral²
}

This study aimed to identify the (in)visibility of nursing care and discuss ways of (dis) articulating this care with family care in the social network of children with special healthcare needs. A qualitative research was performed with health professionals at a pediatric hospital, four units of the Family Medical Program (FMP), and children's relatives living in Niterói (RJ). The field work was put in practice after IRB approval (HESFA/EEAN), consisting of five semi-structured interviews and two group dynamics. Critical Discourse Analysis indicated that nursing care is visible in the child's social network through the nurse's educational and care activities and home visits by the nurisng aide of the FMP. Due to errors in the national health system's referral and counter-referral, mothers articulate the network and not the health service; thus, the reorganization of the system in the State would foster social networks that are less wearing for their families.

Descriptors: Child Health; Child Care; Nursing.

\footnotetext{
${ }^{1} \mathrm{PhD}$, Maternidade Escola, Universidade Federal do Rio de Janeiro, Brazil.
}

${ }^{2} \mathrm{PhD}$, Associate Professor, Escola de Enfermagem Anna Nery, Brazil.

Corresponding Author:

Juliana Rezende Montenegro Medeiros de Moraes

Rua Alfredo Ceschiatti, 105, Bloco I, Apto. 610

Condomínio Rio 2

Barra da Tijuca

CEP: 22775-045, Rio de Janeiro, RJ, Brasil

E-mail: jumoraes@ig.com.br 


\title{
A rede social de crianças com necessidades especiais de saúde na (in) visibilidade do cuidado de enfermagem
}

Objetivou-se, aqui, identificar a (in)visibilidade do cuidado de enfermagem e discutir os modos de (des)articulação desse cuidado com o cuidado familial, na rede social de crianças com necessidades especiais de saúde. Trata-se de pesquisa qualitativa com profissionais de saúde de um hospital pediátrico de quatro unidades do Programa Médico de Família (PMF), e familiares residentes em Niterói, RJ. Operacionalizou-se o trabalho de campo após aprovação pelo Comitê de Ética e Pesquisa (HESFA/EEAN), tendo esse trabalho se constituído de cinco entrevistas individuais semiestruturadas e duas dinâmicas grupais. A Análise Crítica do Discurso apontou que o cuidado de enfermagem é visível na rede social da criança pelas atividades cuidativas e educativas da enfermeira e pela visita domiciliar do auxiliar de enfermagem do PSF. Devido a falhas na referência e contrarreferência do sistema de saúde, a mãe articula a rede e não o serviço de saúde; portanto, a reorganização do sistema, no Estado, promoveria redes sociais menos desgastantes para seus familiares.

Descritores: Saúde da Criança; Cuidado da Criança; Enfermagem.

\section{La red social de niños con necesidades especiales de salud en la (in) visibilidad del cuidar de enfermería}

\begin{abstract}
El objetivo fue identificar la (in) visibilidad del cuidado de enfermería y discutir los modos de (des) articulación de ese cuidado con el cuidado familiar en red social de niños con necesidades especiales de salud. Investigación cualitativa con profesionales de salud de un hospital pediátrico, de cuatro unidades del Programa Médico de Familia (PMF), y familiares residentes en Niterói (RJ). Trabajo de campo fue ejecutado después de aprobación por el Comité de Ética (HESFA/EEAN), consistiendo de cinco entrevistas seme-estructuradas y dos dinámicas grupales. Análisis Critica del Discurso apuntó que cuidado de enfermería es visible en red social del niño por actividades cuidadoras y educativas de enfermera y por visita domiciliar del auxiliar de enfermería del PSF. Debido a fallos en la referencia y contra referencia del sistema de salud, la madre, articula red y no servicio de salud; por tanto la reorganización del sistema en el Estado promovería redes sociales menos desgastantes para familiares.
\end{abstract}

Descriptores: Salud del Niño, Cuidado del Niño, Enfermería.

\section{Introduction}

Children with Special Healthcare Needs (CSHCN) are at greater risk of developing a physical, development, behavioral, emotional or chronic condition, which generally demands a type and quantity of health services that goes beyond other children's requirements. These children's healthcare needs demand care that, when accomplished inadequately, interferes directly in their survival. Many of their needs originate in the therapeutic process to repair their health-disease condition(1).

In Brazil, CSHCN have been classified in five groups, according to a care typology: developmental, technological, medication, modified habitual and mixed demands. The first includes children with neurodevelopmental dysfunction who need psychomotor and social rehabilitation. The second comprises technology-dependent children (semiimplantable catheter, colostomy and ureterostomy bags, tracheostomy tubes, etc.). The third segment refers to drug-dependent children. The fourth covers children who depend on modification in the daily care form, including the accomplishment of common daily life activities. Finally, the fifth group is for children who present one or more of these demands together ${ }^{(2-5)}$. 
Attending to the $\mathrm{CSHCN}^{\prime}$ demands implies the establishment of a social network though, including institutional, family and community participation, which has been little explored so far in research involving this child group. Social networks are collective structures that are capable of making their subjects autonomous, empowered, reflexive and solidary in their actions and relations, aware of their attitudes. Awareness-raising inside the social health care network is only possible when man chooses and decides, gets released instead of submitted, ends up being a subject ${ }^{(6)}$.

In this sense, we focus on the construction of social care networks for CSHCN with a view to identifying the (in)visibility of nursing care and discussing ways to (dis) articulate this care with family care in the CSHCN's social network.

This study is justified by the fact that, in the weaving of these social networks, bonds, interactions and interlocutions need to be built among people (health professionals, nursing professionals, relatives, friends, neighbors, etc.) and places (home, health services, school, church, community, etc.). Also, a permanent movement of articulation needs to be established to grant visibility to nursing care delivery to a social group that is hardly visible in the context of social life. A stable, sensitive, active and reliable social network protects children against avoidable diseases, acts as a helping and forwarding agent. It also influences the pertinence and resolutivity of the health services, accelerates the expected outcomes and/or rehabilitation process, and increases survival. In summary, it generates health(7).

\section{Methods}

This qualitative and descriptive research was developed through the creative and sensitive method(8-9) in three contexts: a pediatric public hospital (G.); Family Medical Program (FMP); the families' homes - all of which were located in the city of Niterói (RJ).

Hospital $G$ is the only hospital in Niterói that attends the child population, offering an intensive care service for children between zero days and 18 years of age. It serves as a referral institution of the National Health System for the entire Metropolitan Region II and the Lake region of Rio de Janeiro state. In the second context, the Family Medical Program in Niterói has been implemented in five geographical areas, with 33 modules and 108 teams. The total population in Niterói corresponds to 476,669 inhabitants, divided in 151,620 families living in private homes. The third context refers to the homes of the families that take care of children with special healthcare needs. Their children have a medical history of recurring rehospitalizations at hospital G. and live in the coverage area of the Family Medical Program in Niterói.

Data sources were the hospital charts of four children, semistructured interviews with one nurse at hospital G. and 04 nursing auxiliaries in the FMP; the creativity and sensitivity dynamics "Mapa Falante" (Speaking Map), involving four families of CSHCN, totaling 12 participants.

The interviewed hospital nurse and FMP nursing auxiliaries complied with the following inclusion criteria: care delivery to $\mathrm{CSHCN}$, familiarity with main caregiving relatives, identification by the family as a reference for nursing care and voluntarily accepting to participate in the research. People on leave in the month data were collected were excluded.

The creativity and sensitivity group dynamics (CSD) adopted the following questions to further debate: Who are the people who take care of ... (child's initials) at home? Where do you turn to when ... needs (health, spiritual, school etc.) care?

Approval for the study was obtained from the Institutional Review Board at HESFA/EEAN (Protocol No. 003/2008) and all participants signed the Free and Informed Consent Term after receiving further information about the study aims.

Two criteria were used to close off the field work ${ }^{(10)}$. The first, concerning internal validity, sought theoretical saturation; and the second, for the sake of external validity, referred to the number of participants in the preceding qualitative studies, to determine the minimum of six and maximum of 12 participants.

Data were analyzed through Critical Discourse Analysis $^{(11)}$, as they entailed discourse markers that reflected power relations, the dominant ideology and the macro-structural context, influencing the constitution of the research participants' statements. Based on Fairclough's(11) three-dimensional analysis framework, textual, discourse practice and social practice analyses were performed.

The discourse practice dimension centers on how discourse is produced in particular ways and in specific social contexts. The nature of these processes varies among different types of discourse and according to social factors. Social practice implies understanding how and why ideology determines people's way of speaking and that power relations are hegemonic to maintain discourse. 
The result of this analysis evidenced the dialectic category of the (in)visibility and (dis)articulation of nursing care in the CSHCN's social network.

\section{Results}

\section{Dialectics of the (in)visibility and (dis)articulation of nursing care in the CSHCN's social network}

Nursing care is (in)visible in the hospital, home and community contexts of the CSHCN's social network in different ways.

I taught (...) at the procedure room. I trained the mother to apply an intermittent urinary catheter. First, I explained to her what a neurogenic bladder was, why the child needed the catheter, how much time it would take to ... wean from that. (...) The mother told me like: Look, now I'm much calmer to take my daughter home (Nurse at Hospital G).

In manifest intertextuality, which involves bringing the other person's voice into the constitution of his/ her saying, the Nurse brought the caregiving relative's discourse into her discursive I to give visibility to her pedagogical approach, training the caregiving mother to apply the urinary catheter. Thus, in the hospital context, nursing care gains visibility and is articulated by the nurse in her pedagogical relation with the CSHCN's mother. The articulation between the nurse and the CSHCN's mother is mediated by a pedagogical model, whose actions are aimed at providing training and explanations about how to apply intermittent urinary catheters, based on the biomedical model, on technological care demands, on the accomplishment of care techniques and on the CSHCN's disease.

This pedagogical model is put in practice in phases: explanation about the disease, training about the technical procedure and demonstrated return in feedback. In the explanation phase, the nurse centers on the illness to explain what a neurogenic bladder is and on the special health needs, which indicates the accomplishment of the procedure and how long the child depends on this special care (to wean from urinary catheters).

In the Nurse's field of perception, explanations on the disease in an appropriate place (procedure room, makes the caregiver feel calmer and safe to deliver care when at home).

What does being trained mean to you? (First author)

It means doing it according to the technique, correctly.

[...] Everything the way I explained to her, so that she can do it safely at home (Nurse at Hospital G).
The hospital nurse's professional knowledge is transmitted for reproduction at home according to scientific and technical principles, which are perfectly justifiable for the hospital environment, without raising any questions on their pertinence and applicability in the home context, which makes it invisible in the latter. In this ideological conception, the complexity and specificity of care delivery to a child with special health needs imply a learning model centered on reproduction, on the depositing of contents, without any critical reflection on its adequacy and pertinence in extra-hospital contexts. The essential importance of care centers on the disease, on the mastery of the technique and on the gaining of motor skills for safe practice. Based on the technique and disease, nursing care gains visibility and the nurse articulates them with caregiving mothers in the hospital environment.

Thus, the nurse's professional ethos ${ }^{(10)}$ is unveiled, its educative and pedagogical approach and the power it exerts on caregivers in the hospital context and on the creation of conditions for hospital discharge. Ethos refers to a participant's comprehensive behavior, whose verbal (spoken and written) style and tone are part of, express the type of person he/she is and indicates his/ her social identity and subjectivity.

Here in the FMP, I and the Dr. (from FMP3) see T. (CSHCN). We take care of T. here in the FMP and in home visits. At home, the grandmother takes care of him (CSHCN) and also takes care of the other grandchildren. Thus, it's the grandmother who does everything that needs to be done with $T$. She (grandmother) washes him, gives him food, takes him to physical therapy, and does everything for that child. On the day of the consultation, I weigh him, check his height, and see if the vaccination record card is update. It's the same for all children (Nursing aid 3 in the Family Medical Program).

Besides the hospital's place in the social network, nursing care gains visibility in the CSHCN's community and home. In the FMP, the nursing aid articulates care, interacting with the caregiving mothers in these children's families. The FMP nursing aide develops community care, in the FMP module, at home, during visits.

In the FMP module, nursing care gains visibility in weight and height measurement to follow growth and development, vaccination record card monitoring, assessment and monitoring consultations, home visits, among others. Thus, community nursing care is dialectically visible through the articulation of the FMP nursing aide and invisible when family members take care of the CSHCN at home and in the community. 
Nursing care in the articulation with family care continued in the discursive invisibility of the nurse who constitutes the social network. In the nurse's discourse, in turn, the relatives' expertise in continuity about care to the CSHCN was not recovered. Other people from the community were not acknowledged as caregivers and FMP professionals remained invisible.

In the creativity and sensitivity dynamics accomplished at home with the CSHCN's family members, the mothers were the participants who most delivered care, serving as the main caregivers and holding power over care in the family group.

The nurses at G. (Hospital) when he was hospitalized taught me [...] (CSHCN T's mother).

The nurses at hospital G. taught T.'s (CSHCN) mother what nursing care she had to accomplish at home.

[...] The nurse at G. explained, showed and let me give the medicine (CSHCN A's mother).

[...] She (CSHCN) asks for a kiss, wants a hug [...], and I don't even know how (CSHCN A's father).

Nursing care is sometimes visible and sometimes invisible in the discourse of nursing professionals who are part of the CSHCN's social network; especially through the discourse markers of what nursing teaches, explains, orients and does with the mothers in the hospital. Thus, the mothers, the CSHCN's primary caregivers at home, attribute a new meaning to this care based on the knowledge gained from their experience, little concerned with technique and the disease. The knowledge that supports affective care is built through experience, and not through contact with the nurse in pedagogical practice. The pedagogical model of transmission and reproduction, in turn, plays a central role in educative practice, without departing from the learning needs of the people being taught.

In the hospital context, nursing care gained visibility in the pedagogical actions of explaining, demonstrating and allowing caregivers to perform the care. The mother-nurse and nurse-mother bonds were perceived as harmonic, but the nurse serves as an educator by transmitting contents mediated by a pedagogical training model. At the same time as nurses hold the hegemonic power in hospital to develop a pedagogy of technical content transmission, they hardly value the relational knowledge that supports affective care (asks for a kiss, wants a hug), which the child demands, but which the family does not know how to practice at first, and learns as the care time advances, in the family relation and with the FMP teams. In the dynamics, the father announced the need to value the expertise of relatives whose knowledge is gained through experience.

When J. (CSHCN) left the hospital and came home, she (nursing aide) came her with the doctor for home visits. She was always concerned with knowing whether everything was alright (CSHCN J's mother).

In the home context, nursing aides' articulation in the CSHCN's social network centers on the family members, who articulate the family care and community care FMP professionals develop.

FMP nursing aides deliver community nursing care always linked with the physician, and are sometimes visible and at other times invisible in this network. That is so as the historical and cultural bases for the implementation of the Family Medical Program attempt to break with physicians' actions as specialists in the biomedical model and aim to structure a family-centered community model(12). In this change, however, it is the physician who is visible, and not the nurse. Nurses working at the central level are active in the management of nursing actions. Thus, nursing and community nursing care are situated in the discourse practice of the nursing aides who live in the client coverage are and are part of the CSHCN's social network. Consequently, the nursing aides' discourse practices point towards a stronger social practice of bonding with the clientele, together with the physicians, than with nurses from the central FMP level, which reflected in the FMP nurse's invisibility in the social network.

\section{Discussion}

In Freire's $\mathbf{s}^{(13)}$ perspective, beings are social because they are inserted in and establish social relations with the world. In that sense, the hospital and the home where family members and children with special health needs pass by are parts of this relational world, in which social interactions happen and generate sources of learning and knowledge.

When learning to talk, human beings also learn to think, to the extent that each words reveals the experiences and values of their culture. From this perspective, the verbal influences our way of perceiving reality and the word plays a mediating role between the social and the individual(6).

As human being man is an unfinished being, who is always seeking answers to challenges, it is believed that taking care of a child with special health needs demands articulation among people and places inserted in a social network. In Freire's perspective, family caregivers 
are relational beings, capable of gaining awareness of their reality, and thus deliver care to the CSHCN in the home context that promotes wellbeing. Therefore, care delivery to the CSHCN takes place through the sharing of experiences among health professionals at the hospital, in the FMP and family caregivers, who are constantly interacting mutually and with others. The human self is an intertext, does not exist alone, its life experience is woven, intertwined and interpenetrated with the other. Taking care of oneself and the other is not easy, mainly when the other is a child with special health needs, who solely and uniquely depends on the other to live and have his/her voice in the world.

What distinguishes humans from other beings is their ability to respond to the different challenges reality imposes $^{(13)}$. But the apprehension of reality and action in the world do not happen alone. It is in the relation among family caregivers, health professionals and the community and between the former and the world that a new reality is constructed and new men and women are made, which grants power.

Teaching does not mean transferring knowledge, but creating possibilities for one's own production or construction, as it demands critical sense and respect for the learner's autonomy. If not, bulletins, cultural extension and invasion will happen, instead of true communication ${ }^{(6,13)}$. Dialogue is an existential requirement. And, if it represents the meeting in which the reflections and actions of its subjects meet, addressed to the world that needs to be transformed and humanized, it cannot be reduced to a mere depositary act of one subject in the other, nor can it become a mere exchange of ideas subjects need to consume ${ }^{(6)}$.

Therefore, the "pyramidal" structure of health services needs to be reconsidered and, also, it needs to be understood that all services are committed to comprehensiveness - and attentive listening -, even those that are considered final and extremely specialized. This demands radicalizing the idea that each person, with his/her multiple and singular needs, should always be the focus, the reason for the existence of each service and the "system" as a whole ${ }^{(13-15)}$.

The social practice of family care is centered on the family and community model, in the demand for modified habitual care, including affective care. Nursing care is more visible in the hospital context, as nurses enhance its articulation with the pedagogical process during hospitalization. The multiple voices ${ }^{(10)}$ identified nurses pedagogical role to teach, train, orient the CSHCN's mothers within a model of information depositing, which does not value caregiving relatives in their expertise gained through experience. Thus, relations of power and domination over caregiving mothers prevail in the hospital context(13).

At home, family care is mainly developed by caregiving mothers who, mediated by family and community knowledge, attribute a new meaning to the knowledge of hospital nurses, and also to the nursing knowledge FMP nursing aides mediate. Thus, they look for the other in themselves, i.e. what is left of the nurse's voice in each caregiver and what can be applied to the experience of care delivery to the CSHCN in the hospital and at home. Thus, nursing care is dialectically visible and invisible in the home and community contexts, articulated and disarticulated with family care.

In the dialectics of the (in)visibility and (dis) articulation of care to the CSHCN in the social network, caregiving relatives continue with their naïve view on reality and do not reach the stage of critical sense ${ }^{(13)}$. Without a critical spirit, they continue as passive subjects in the world that surrounds them, enhancing the relation of subordination, dependence and conformism. Hence, the nursing care that was visible in the hospital context becomes dialectically invisible, and the solutions found are not always the healthiest or most damage-reducing voices, contributing to the circle of hospitalizations discharges - rehospitalizations ${ }^{(14)}$.

The understanding of social networks as relations that comprise not only the core or extensive family, but also broader interpersonal bonds, including: friends, colleagues or study partners and relations established in the community. Thus, they sustain and are part of the individual's relational universe( ${ }^{(7,15-17)}$.

\section{Conclusions and implications for practice}

Nursing care gained visibility in the multiple voices that constituted the mothers, nurse and FMP nursing aides' statements, as these are relational subjects who dialogue in and with the world, in constant interaction with the "I" and the dialogical "other". The nursing professionals' (hospital nurse and FMP nursing aides) and families discourse dialectically (dis)articulated nursing care, as it made care acts sometimes visible and sometimes invisible. This care is part of the full range of care in these children's social network, who constitute an emerging group in Brazilian society. The dialectics of the visibility and invisibility of nursing care in the articulation of the CSHCN's social network entails implications for professional practice that unfold in three aspects. 
The first is to broaden the hospital's social network, so as to include, besides the mother, other family members, as excessive demands on the womanmother can lead to caregivers' physical and emotional exhaustion. At home, other family and community members will participate in this care. The second aspect is to enhance caregivers' empowerment to reduce dependence on health services and to strengthen family competences. These are considered as the set of knowledge, practices and skills needed to promote the children's survival, development, protection and participation in the care process. The third aspect is based on the wider visibility of nursing care within the CSHCN's care demands, strengthening nursing as a part of these children's social network.

Thus, the intent is to contribute to the elaboration of specific public policies for CSHCN, which locate Nursing at the homes, taking care of the $\mathrm{CSHCN}$ as, even if mothers and families are trained for care delivery, they do not have the knowledge inherent in nursing. In care, nurses' hegemonic power needs to be reconsidered, in the attempt to break with the biomedical hospital model, making room for an emerging care model that values families and communities as central and permanent in the children's lives. The relevance of care delivery to CSHCN needs to be incorporated in Pediatric Nursing teaching, enhancing the visibility of care demands and articulating them with the contexts they pass through.

One study limitation is that the children with special health needs were not given voice.

\section{References}

1. National Center on Financing for Children with Special Health Care Needs. Chart Book: CSHCN in Medicaid, SCHIP, and Title V. USA: University of Florida; 2004.

2. Rezende JMM, Cabral IE. As condições de vida das crianças com necessidades especiais de saúde: determinantes da vulnerabilidade social na rede de cuidados em saúde as crianças com necessidades especiais de saúde. Rev Pesq Cuid Fundam. out-dez 2010;2(Ed. Supl.):22-5.

3. Neves ET, Cabral IE. A fragilidade clínica e a vulnerabilidade social das crianças com necessidades especiais de saúde. Rev Gaúcha Enferm. jun 2008;29(2):182-90.

4. Neves ET, Cabral IE. Cuidar de crianças com necessidades especiais de saúde: desafios para as famílias e enfermagem pediátrica Rev Eletr Enferm. [periódico na Internet]. 2009. [acesso 9 dez 2009]; 11(3):527-38. Disponível em:http://www.fen.ufg.br/ revista/vl l/n3/vl In3a09.htm
5. Fereday J, Oster C, Darbyshire P. Partnership in practice: what parents of a disabled child want from a generic health professional in Australia. Health Soc Care Commun. 2010;18(6):624-32.

6. Gehlen TS, Maldaner AO, Delizoicov D. Freire e Vygotsky: um diálogo com pesquisas e sua contribuição na Educação em Ciências. Pro-Posições. jan/abr 2010;21(61):129-48.

7. Ribeiro KSQS, Ampliando a atenção à saúde pela valorização das Redes sociais nas práticas de educação popular em saúde. Rev APS. jul-set 2008;11(3):235-48. 8. Neves ET, Cabral IE. O empoderamento da mulher cuidadora de crianças com necessidades especiais de saúde. Texto Contexto Enferm. jul-set 2008;17(3):552-60.

9- Motta MGC, Issi HB, Ribeiro NRR. Grupos como estratégia de ensino e cuidado, de família, criança e adolescente com doença crônica. Cienc Cuid Saúde. 2009;8(supl):155-61.

10. Fontanella BJB, Ricas, J, Turato, ER. Amostragem por saturação em pesquisas qualitativas: contribuições teóricas. Cad Saúde Pública. jan 2008;24(1):17-27.

11. Fairclough N. A dialética do discurso. Rev Teias. maiago 2010;11(22)225-34.

12. Hübner LCM, Franco TB. O Programa Médico de Família de Niterói como Estratégia de Implementação de um Modelo de Atenção que Contemple os Princípios e Diretrizes do SUS. PHYSIS: Rev Saúde Coletiva. 2007;17(1):173-91.

13. Peloso FC, Paula EMAT. Recriando Paulo Freire na educação da infância das classes populares. Educ Linguagem. jul-dez 2010;13(22):259-76.

14. Silveira CL, Budó MLD, Silva FM, Beuter M, Schimith MD Rede social das cuidadoras de familiares com doença crônica incapacitante. Cienc Cuid Saúde. out-dez 2009;8(4):667-74.

15. Wegner W, Pedro ENR. Concepções de saúde sob a ótica de mulheres cuidadoras-leigas,acompanhantes de crianças hospitalizadas. Rev. Latino-Am. Enfermagem. jan-fev 2009;17(1):88-93.

16. Marques E, Bichir R. Redes de apoio social no Rio de Janeiro e em São Paulo. Rev Novos Estudos. jul 2011;90(1):65-83.

17. Tavares ANCR, Ferreira ATB. Práticas e eventos de letramento em meios populares: uma análise das redes sociais de crianças de uma comunidade da periferia da cidade do Recife. Rev Bras Educ. mai-ago 2009;14(41):258-68.

Received: June $9^{\text {th }} 2011$ Accepted: Feb. $29^{\text {th }} 2012$ 